"This is the peer reviewed version of the following article Chem. Eur. J. 2016, 22 (25), 8571 , which has been published in final form at [10.1002/chem.201600390]. This article may be used for non-commercial purposes in accordance with Wiley Terms and Conditions for Self-Archiving."

\title{
SELF-ASSEMBLY OF URANYL-PEROXIDE NANOCAPSULES IN BASIC PEROXIDIC ENVIRONMENTS
}

\author{
Pere Miró,,$^{\dagger}{ }^{*}$ Bess Vlaisavljevich,${ }^{\dagger}$ A. Gil,${ }^{\S}$ Peter C. Burns,${ }^{\dagger}$ May Nyman, and Carles Bo ${ }^{\S, \Omega}$ \\ ${ }^{\dagger}$ Department of Chemistry, Supercomputing Institute, and Chemical Theory Center University of Minnesota, Minneapolis, \\ Minnesota USA. "Department of Civil Engineering and Geological Sciences, University of Notre Dame, South Bend, Indiana \\ USA. ${ }^{\diamond}$ Materials Science of Actinides Department of Chemistry, Oregon State University, Gilbert Hall, Corvallis, Oregon \\ 97331, United States, ${ }^{\S}$ Institute of Chemical Research of Catalonia, ICIQ, Avda. Països Catalans 16, 43007 Tarragona, \\ Spain ${ }^{\Omega}$ Departament de Química Física i Inorgànica, Universitat Rovira i Virgili, Campus Sescelades, Tarragona, Spain
}

KEYWORDS. Uranyl, Peroxide, Density Functional Theory, Counterions, Nanocapsules.

This paper is dedicated to the memory of our colleague Prof. Tom Ziegler.

ABSTRACT: A wide range of uranyl-peroxide nanocapsules have been synthesized using very simple reactants in basic media; however, little is known about the process to form these species. We have performed a density functional theory study of the speciation of the uranyl ions under different experimental conditions and explored the formation of dimeric species via a ligand exchange mechanism. We shed some light onto the importance of the excess of peroxide and alkali counterions as a thermodynamic driving force towards the formation of larger uranyl-peroxide species.

\section{Introduction}

Uranium is the second most abundant actinide on Earth and a major source of energy as a fissile material. As a result, 63,000 tons of nuclear waste are now stored in the U.S. alone, while tens of thousands of tons more are produced worldwide each year. ${ }^{1}$ Therefore, it is not surprising that understanding the solution chemistry of the uranyl ion, $\left[\mathrm{U}^{\mathrm{VI}} \mathrm{O}_{2}\right]^{2+}$, is central to an advanced nuclear energy cycle including fuel reprocessing.

With the goal of developing nanoscale control of the actinides, one of the authors has led the development of a family of polyperoxometalate nanocapsules built from uranyl and neptunyl polyhedra bridged through peroxide ligands. ${ }^{2-4}$ Hydroxyl, pyrophosphate or oxalate ligands and/or transition metal polyoxometalate fragments can also be included and increase the diversity of accessible capsules topologies. ${ }^{5-16}$ These capsules contain up to 120 actinyl moieties and exhibit a wide variety of high symmetry topologies including several fullerenes. ${ }^{17-21}$ The actinyl ions are coordinated through six ligands arranged at the equatorial vertices of hexagonal bipyramids as observed in uranyl-peroxide minerals. ${ }^{22-24}$ Moreover, the butterfly bending of the actinyl-peroxide An- $\left(\mathrm{O}_{2}\right)$-An moiety introduces curvature and encourages nanocluster closure. The selfassembly of these species in aqueous solution under ambient conditions is unique in uranium and neptunium chemistry and has a wide range of potential applications in the fabrication and reprocessing of actinide-based materials. ${ }^{25,26}$ Additionally, the potential importance of this field in actinide transport following nuclear accidents has recently been discussed. ${ }^{27}$

In alkaline solutions, actinyl peroxide polyhedra self-assemble into capsules rapidly, making it difficult to isolate fragments prior to their assembly into completed clusters. However, the isolation of a few building blocks has been achieved by the addition of oxalate groups as equatorial ligands for the uranyl ions. Three such building blocks are $\left[\left(\mathrm{UO}_{2}\right)_{2}\left(\mu^{2}-\right.\right.$ $\left.\left.\mathrm{O}_{2}\right)\left(\mathrm{C}_{2} \mathrm{O}_{4}\right)_{4}\right]^{6-},\left[\left(\mathrm{UO}_{2}\right)_{5}\left(\mu^{2}-\mathrm{O}_{2}\right)_{5}\left(\mathrm{C}_{2} \mathrm{O}_{4}\right)_{5}\right]^{10-}$ and $\left[\left(\mathrm{UO}_{2}\right)_{6}\left(\left(\mu^{2}-\mathrm{O}_{2}\right)_{6}\left(\mathrm{C}_{2} \mathrm{O}_{4}\right)_{6}\right]^{12-} \cdot{ }^{19}\right.$ A fourth building block, $\left[\left(\mathrm{UO}_{2}\right)_{4}\left(\mu^{2}-\mathrm{O}_{2}\right)_{4}\left(\mathrm{C}_{2} \mathrm{O}_{4}\right)_{4}\right]^{8-}$, was previously proposed theoretically based on the capsules' topologies, but has now also been isolated in the solid state. ${ }^{12,28,29}$ Recently, Zanonato et al. identified uranyl-hydroxide-peroxide species in solution using calorimetric, potentiometric, and spectrophotometric techniques. ${ }^{30-32}$ They have also proposed these intermediates as building blocks for the nanocapsules. ${ }^{33}$

Among these building blocks, a dimer containing two uranyl ions bridged by a bidentate peroxo ligand is central for understanding the initiation of the growth mechanism 


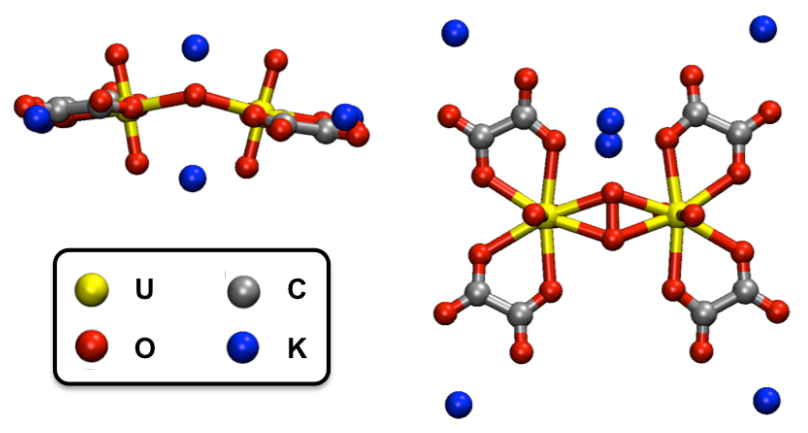

Figure 1. The X-ray structure of the uranyl peroxide dimer, $\left.\mathrm{K}_{6}\left[\left(\mathrm{UO}_{2}\right)_{2}\left(\mu^{2}-\mathrm{O}_{2}\right)\left(\mathrm{C}_{2} \mathrm{O}_{4}\right)_{4}\right]\right]^{19}$ Four potassium cations are coordinated to the equatorial oxalate ligands. Meanwhile the remaining cations are located above and below the $\mathrm{U}_{-} \mathrm{O}_{2}-\mathrm{U}$ moiety.

of the capsules (Figure 1). Furthermore, the recent use of organic ligands such as picolinate or pyridine-2,6-dicarboxylate allowed for the isolation of several uranyl-peroxide dimers. ${ }^{34}$ Density functional theory (DFT) and complete active space self-consistent field (CASSCF) calculations have been used to study the electronic structure and bonding of uranyl-peroxide dimers. ${ }^{29,34,35}$ While uranyl-peroxide bonding in these species is mainly ionic, some covalent contributions are observed. These orbital interactions are responsible for the slight favoring of butterfly bending in the $\mathrm{U}_{-} \mathrm{O}_{2}-\mathrm{U}$ moiety, effectively minimizing the repulsion between adjacent peroxo moieties and enhancing charge delocalization. $\mathrm{However}_{\mathrm{H}} \mathrm{U}-\mathrm{O}_{2}-\mathrm{U}$ dihedral angle is highly pliable and bending the angle from planar to $130^{\circ}$ gains only a few kcal $/ \mathrm{mol} .{ }^{34}$ Furthermore, the alkali cations used as counterions during the synthesis of uranyl-peroxide nanocapsules play a critical role in solution. The $\mathrm{U}-\mathrm{O}_{2}-\mathrm{U}$ dihedral angle is influenced by the presence of nearby alkali counterions, and the curvature of the resulting nanocapsules is likely controlled, to some extent, by cation coordination. ${ }^{29,34,36}$ In consequence, alkali cations have been proposed as one of the factors contributing to the formation of building blocks suitable to self-assemble into nanocapsules $a$ posteriori. There are fewer studies on neptunyl-peroxide nanocapsules; however, a similar coordination chemistry is expected but with richer electrochemistry since both +5 and +6 oxidation states persist in aqueous solution.2,3

During the past few years, several computational studies on uranyl-peroxide nanocapsules have been published;29,34-38 however, the reactivity corresponding to the growth of these species and the role of the alkali counterions is not yet well understood. 39,40 Moreover, in the growth of transition-metal-containing polyoxometalates, mechanistic studies are rare. Only recently has the formation mechanism of the small polyoxometalates been proposed. ${ }^{41,42}$ Here we present the first study on the growth of uranyl-peroxide dimers in basic peroxidic environments and their evolution towards larger aggregates.

\section{Computational Details}

All species were fully optimized without any symmetry constraints using the density functional theory implementation in the Amsterdam Density Functional package (ADF2013).43-45 We used the local VWN exchange-correlation potential with nonlocal Perdew-Bruke-Ernzerhof exchange-correlation correction (PBE). ${ }^{46}{ }^{47}$ Relativistic corrections were introduced by the scalar-relativistic zero-order regular approximation (ZORA). ${ }^{48,49}$ A triple- $\zeta$ plus one polarization function basis set was used on all atoms. For non-hydrogen atoms, a small relativistic frozen-core potential was used.

The nature of all stationary points was verified by analytic computation of vibrational frequencies, which were also used for the computation of zero-point vibrational energies and molecular partition functions. Partition functions were used in the computation of $298.15 \mathrm{~K}$ thermal contributions to free energies employing the usual ideal-gas, rigid-rotator, quasiharmonic oscillator approximation. ${ }^{50}$ In the quasiharmonic oscillator approximation, all frequencies below $50 \mathrm{~cm}^{-1}$ were replaced by $50 \mathrm{~cm}^{-1}$ when computing vibrational free energies, thereby avoiding complications associated with the breakdown of the harmonic oscillator approximation for very-low-frequency normal modes. Some species presented small imaginary frequencies corresponding to the rotational motion of water and hydroxo ligands that were also replaced by $50 \mathrm{~cm}^{-1}$ when computing thermal and vibrational contributions to the Gibbs free energy.

Solvent effects were introduced using the continuous solvent model COSMO with Allinger radii, except for the alkali cations where radii were chosen that accurately reproduce their solvation energy. ${ }^{51-54}$ Two different values of $\mathrm{pH}$ were considered, one equal to the first proton of $\mathrm{H}_{2} \mathrm{O}_{2} \mathrm{pK}_{\mathrm{a}}(\mathrm{pH}=11.62)$ and the another was estimated based on the typical experimental conditions $(\mathrm{pH}=9.00) .19,55$ These values of $\mathrm{pH}$ determine the corrections for the hydroxide ions in the non-standard state. ${ }^{19}$ The concentrations from the synthesis of $\mathrm{K}_{6}\left(\mathrm{H}_{2} \mathrm{O}\right)_{4}\left[\left(\mathrm{UO}_{2}\right)_{2}\left(\mathrm{O}_{2}\right)\left(\mathrm{C}_{2} \mathrm{O}_{4}\right)_{4}\right]$ were used in the non-standard state corrections. A concentration of $0.10 \mathrm{M}$ was used for all uranyl-peroxide species, $1.60 \mathrm{M}$ for alkali ions, $1.96 \mathrm{M}$ and $0.196 \mathrm{M}$ for hydrogen peroxide at $\mathrm{pH} 11.62$ and 9.00, respectively, and 55.6 $\mathrm{M}$ for water as the 


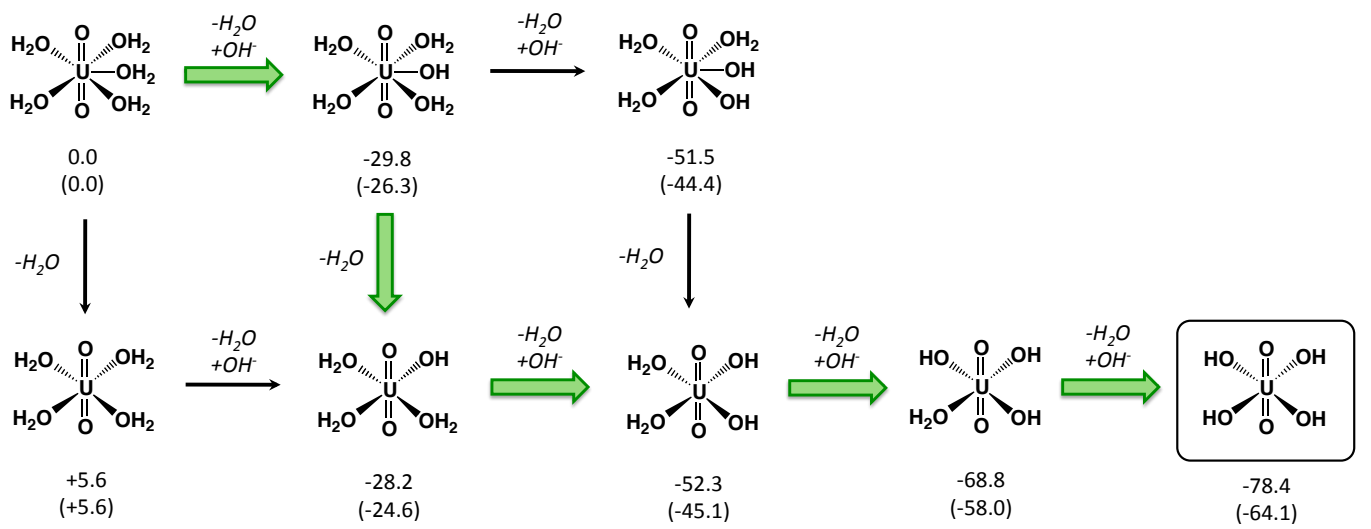

Figure 2. Speciation of $\left[\left(\mathrm{UO}_{2}\right)\left(\mathrm{H}_{2} \mathrm{O}\right)_{5}\right]^{2+}$ at $\mathrm{pH}=11.62(\mathrm{pH}=9.00$ in parentheses) at the PBE/ZORA-TZP/COSMO level of theory. Horizontal arrows represent water/hydroxo ligand exchange reactions and vertical arrows are water decoordination reactions. The most favorable species are highlighted in a box and green arrows indicate the most favored speciation pathway. All energies are Gibbs free energies in $\mathrm{kcal} / \mathrm{mol}$ relative to $\left[\left(\mathrm{UO}_{2}\right)\left(\mathrm{H}_{2} \mathrm{O}_{5}\right)^{2+}\right.$.

solvent. Thus, the free energy in aqueous solution is computed as the $1 \mathrm{~atm}$ gas-phase free energy, plus an adjustment to the non-standard state concentration change, which at $298 \mathrm{~K}$ is $-1.37,0.28$ and $0.40 /-0.97 \mathrm{kcal} /$ mol for uranyl-peroxide, alkali ions, and hydrogen peroxide (pH 11.75 and 9.00), respectively. This approach was validated using a thermodynamic model at equilibrium conditions (see Supporting Information for details).

Single point calculations on the PBE optimized geometries of monomers and dimers were performed using the B3LYP exchange-correlation functional. Gibbs free energy was extrapolated as $G^{\mathrm{B} 3 \mathrm{~L} Y \mathrm{P}}=\mathrm{E}^{\mathrm{B} 3 \mathrm{LYP}}+\mathrm{G}^{\mathrm{PBE}}-\mathrm{E}^{\mathrm{PBE}}$. Since the results at B3LYP/TZP level of theory are very similar to the ones at PBE/TZP, they are only mentioned briefly here but are presented in full in the supporting information.

\section{Results}

Uranyl ion speciation in basic media. In aqueous solution at neutral $\mathrm{pH}$ the uranyl ion coordinates five waters in its equatorial plane, $\left[\left(\mathrm{UO}_{2}\right)\left(\mathrm{H}_{2} \mathrm{O}\right)_{5}\right]^{2+}$; however, its speciation in high $\mathrm{pH}$ remains controversial due to the formation of dimers, trimers, and tetramers. ${ }^{56-58}$ On one hand, it has been established that one of the most abundant species in strongly basic media is $\left[\left(\mathrm{UO}_{2}\right)(\mathrm{OH})_{4}\right]^{2-58}$ On the other hand, at milder $\mathrm{pH}$ conditions a myriad of species coexist, which becomes even more complex with the presence of coordinating ligands such as oxalic acid, if tetra-methyl ammonium ions are present, or when $\mathrm{Li}_{4}\left[\left(\mathrm{UO}_{2}\right)\left(\mathrm{O}_{2}\right)_{3}\right]$ is used as the initial uranyl source during the synthesis of uranyl-peroxide nanocapsules instead of $\left[\left(\mathrm{UO}_{2}\right)\left(\mathrm{NO}_{3}\right)_{2}\right] .33,40$ In the latter case, the dissolution of $\mathrm{Li}_{4}\left[\left(\mathrm{UO}_{2}\right)\left(\mathrm{O}_{2}\right)_{3}\right]$ in aqueous solution leads to the $\left[\left(\mathrm{UO}_{2}\right)\left(\mathrm{O}_{2}\right)_{3}\right]^{4-} \mathrm{species}$ which is unreactive towards the formation of uranyl-peroxide nanocapsules in the absence of an excess of peroxide or a redox active transition metal ion such as copper. ${ }^{39}$ Consequently, we initially studied the speciation of $\left[\left(\mathrm{UO}_{2}\right)\left(\mathrm{H}_{2} \mathrm{O}\right)_{5}\right]^{2+}$ under the experimental $\mathrm{pH}$ conditions used in the synthesis of uranyl-peroxide nanocapsules but prior to the addition of the hydrogen peroxide (Figure 2).

At both studied $\mathrm{pH}$ conditions $(\mathrm{pH}=11.62$ and $\mathrm{pH}=9.00)$, the penta-aquo species spontaneously forms a hydroxo equatorial ligand leading to the $\left[\left(\mathrm{UO}_{2}\right)(\mathrm{OH})\left(\mathrm{H}_{2} \mathrm{O}\right)_{4}\right]^{+}$species through a water/hydroxo ligand exchange. This species spontaneously decoordinates a water ligand to form $\left[\left(\mathrm{U}^{\mathrm{VI}} \mathrm{O}_{2}\right)(\mathrm{OH})\left(\mathrm{H}_{2} \mathrm{O}\right)_{3}\right]^{+}$that rapidly evolves to the expected tetrahydroxo species $\left[\left(\mathrm{UO}_{2}\right)(\mathrm{OH})_{4}\right]^{2-}$ through a cascade of water/hydroxo ligand exchange reactions.

Uranyl-peroxide speciation in basic media. Once the dominant species derived from different uranyl species had 


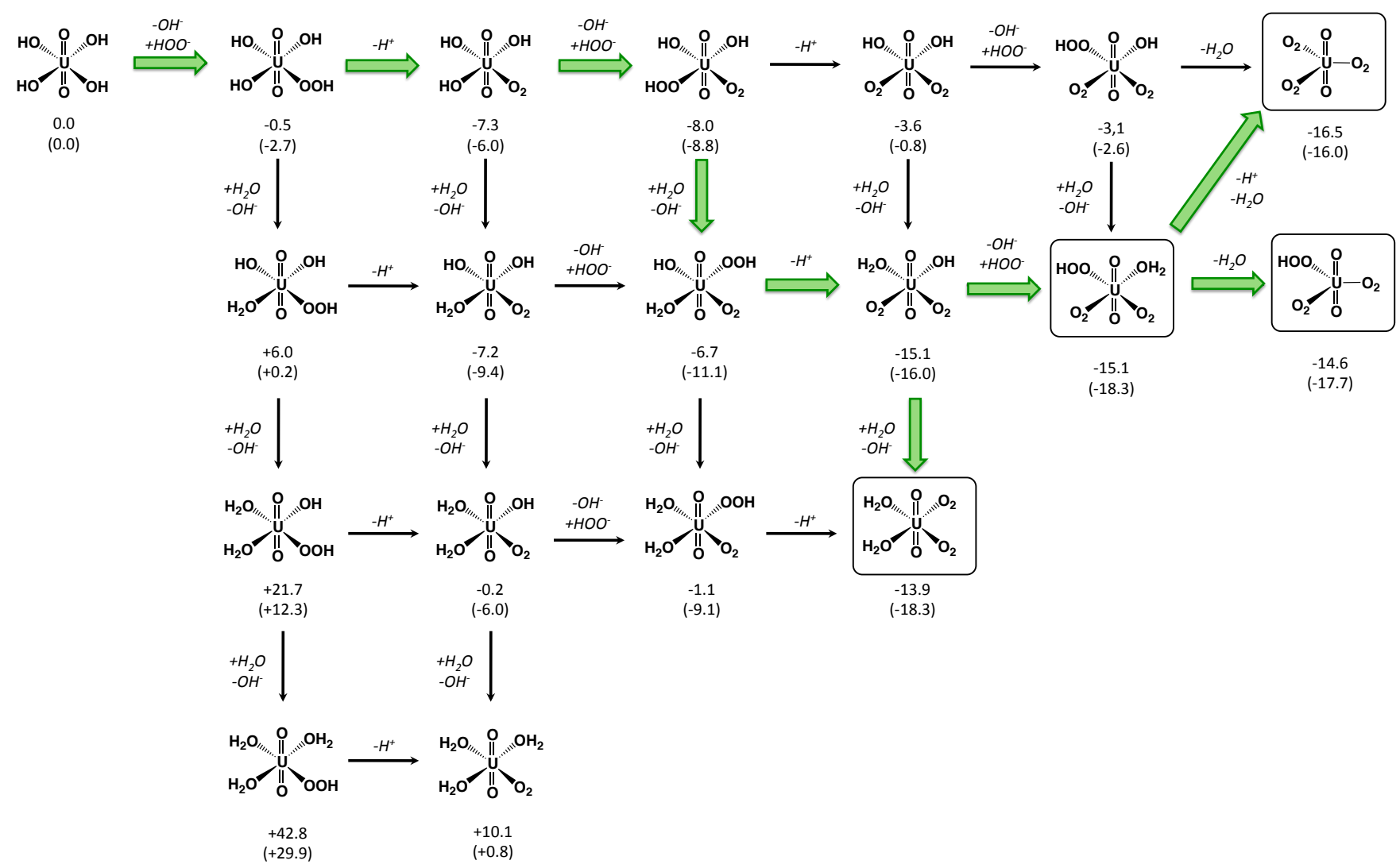

Figure 3. Speciation of $\left[\left(\mathrm{UO}_{2}\right)(\mathrm{OH})_{4}\right]^{2-}$ at $\mathrm{pH}=11.62(\mathrm{pH}=9.00$ in parentheses) in the presence of peroxide at the PBE/ZORATZP/COSMO level of theory. Horizontal arrows represent a hydroxo/hydroperoxo ligand exchange, hydroperoxo deprotonation, or water decoordination reactions, while vertical arrows are hydroxo/water ligand exchange reactions and diagonal arrows are water decoordination and hydroperoxo deprotonation reactions. The most favorable species are highlighted in a box and green arrows indicate the most favored speciation pathway. All energies are Gibbs free energies in $\mathrm{kcal} / \mathrm{mol} \mathrm{rela-}$ tive to $\left[\left(\mathrm{UO}_{2}\right)(\mathrm{OH})_{4}\right]^{2}$.

a)

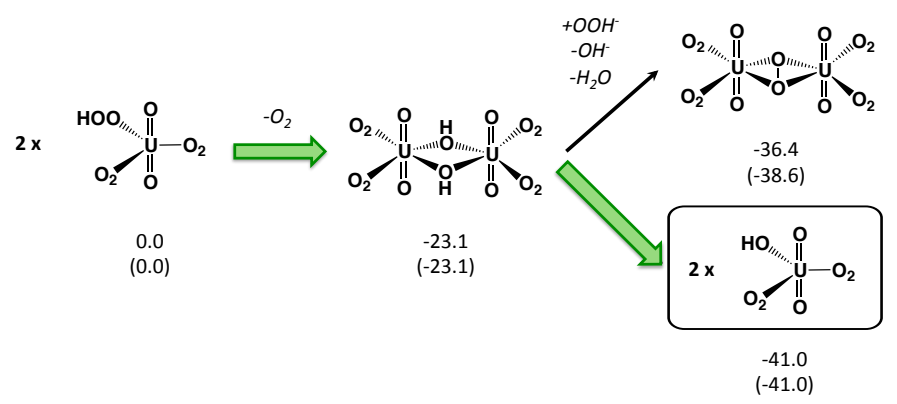

b)

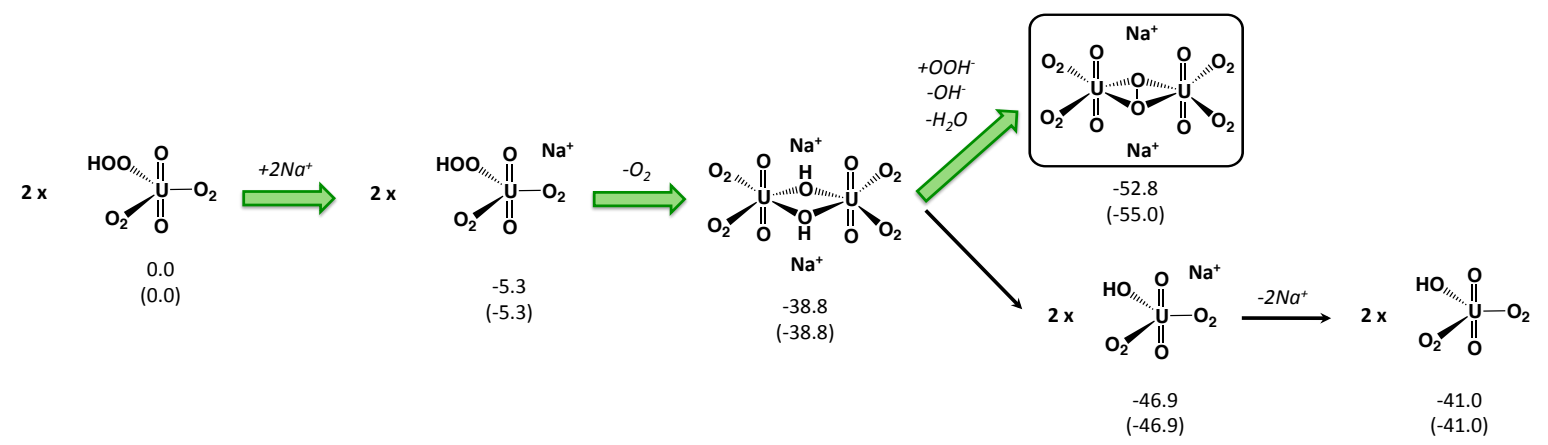

Figure 4. Dimerization of $\left[\left(\mathrm{UO}_{2}\right)(\mathrm{OOH})\left(\mathrm{O}_{2}\right)_{2}\right]^{3-}$ in the absence of alkali counterions (a) and in the presence of $\mathrm{Na}^{+}(\mathrm{b})$ at $\mathrm{pH}=11.62$ ( $\mathrm{pH}=9.00$ in parentheses) at the PBE/TZP level of theory. The most favorable species are highlighted in a box and green arrows indicate the most favored speciation pathway. All energies are Gibbs free energies in $\mathrm{kcal} / \mathrm{mol}$ relative to $\left[\left(\mathrm{UO}_{2}\right)(\mathrm{OOH})\left(\mathrm{O}_{2}\right)_{2}\right]^{3-}$. 
been established, we considered the effects of the source of peroxide $\left(\mathrm{H}_{2} \mathrm{O}_{2}\right)$. The pKa values of hydrogen peroxide are 11.62 and $>14$ for consecutive protons, leading to a $1: 1$ ratio of $\mathrm{H}_{2} \mathrm{O}_{2}$ and $\mathrm{HOO}^{-}$species at $\mathrm{pH} 11.62$ while the concentration of $\mathrm{HOO}^{-}$ is expected to be low at $\mathrm{pH}$ 9.00. However, only HOO- has been considered for the purpose of determining the speciation herein. ${ }^{55}$ The speciation with the addition of $\mathrm{H}_{2} \mathrm{O}_{2}$ (as $\left.\mathrm{HOO}^{-}\right)$to[( $\left.\left.\mathrm{UO}_{2}\right)(\mathrm{OH})_{4}\right]^{2-}$ is presented in Figure 3.

The ligand exchange between an equatorial hydroxo ligand and a hydroperoxo ( $\left.\mathrm{HOO}^{-}\right)$in $\left[\left(\mathrm{UO}_{2}\right)(\mathrm{OH})_{4}\right]^{2-}$ and the deprotonation of the newly formed hydroperoxo rapidly leads to the formation of an equatorial $\eta^{2}-\mathrm{O}_{2}$ moiety. An analogous reaction occurs in the $\left[\left(\mathrm{UO}_{2}\right)(\mathrm{OH})_{3}\left(\mathrm{O}_{2}\right)\right]^{3-}$ species but after the hydroperoxo moiety is formed in $\left[\left(\mathrm{UO}_{2}\right)(\mathrm{OH})_{2}\left(\mathrm{OOH}^{3}\left(\mathrm{O}_{2}\right)\right]^{3-}\right.$, an equatorial hydroxo ligand is replaced by a water molecule leading to the formation of $\left[\left(\mathrm{UO}_{2}\right)(\mathrm{OH})\left(\mathrm{H}_{2} \mathrm{O}\right)(\mathrm{OOH})\left(\mathrm{O}_{2}\right)\right]^{2-}$ prior to the deprotonation of the hydroperoxo moiety to form $\left[\left(\mathrm{UO}_{2}\right)(\mathrm{OH})\left(\mathrm{H}_{2} \mathrm{O}\right)\left(\mathrm{O}_{2}\right)_{2}\right]^{3-}$. On one hand, at $\mathrm{pH}=11.62$ and $\left[00 \mathrm{H}^{-}\right.$ ]$=1.96 \mathrm{M}$, this species leads to the formation of the expected $\left[\left(\mathrm{UO}_{2}\right)\left(\mathrm{O}_{2}\right)_{3}\right]^{4-}$ species. On the other hand, at lower $\mathrm{pH}$, and when the concentration of free hydroperoxo has decreased, several species are nearly isoenergetic and we expect all of them to be present in solution. These species are $\left[\left(\mathrm{UO}_{2}\right)\left(\mathrm{H}_{2} \mathrm{O}\right)_{2}\left(\mathrm{O}_{2}\right)_{2}\right]^{2-},\left[\left(\mathrm{UO}_{2}\right)\left(\mathrm{H}_{2} \mathrm{O}\right)(\mathrm{OOH})\left(\mathrm{O}_{2}\right)_{2}\right]^{3-}$ and $\left[\left(\mathrm{UO}_{2}\right)\left(\mathrm{OOH}^{3}\right)\left(\mathrm{O}_{2}\right)_{2}\right]^{3-}$. The relative stability of these species changes slightly at the B3LYP/TZP level of theory; however, independently of the DFT exchangecorrelation functional used the same species are expected to be present in solution.

Dimerization of uranyl-peroxide species. Once the most stable monomeric uranyl-peroxide species had been determined, we studied the dimerization process that will form cyclic precursors and ultimately uranyl-peroxide nanocapsules. Initially we did not include any alkali counterions in our reactions and only studied the dimerization of $\left[\left(\mathrm{UO}_{2}\right)\left(\mathrm{OOH}^{2}\left(\mathrm{H}_{2} \mathrm{O}\right)\left(\mathrm{O}_{2}\right)_{2}\right]^{3-} \mathrm{spe-}\right.$ cies. Liao et al. demonstrated that the dimerization process cannot proceed without an excess of peroxide thereby demonstrating the fundamental importance of the redox chemistry of peroxide on the reaction. ${ }^{39}$ Furthermore, it is well known that $\mathrm{O}_{2}$ is generated during the formation of uranyl-peroxide nanocapsules as the peroxide is reduced. ${ }^{2,5}$ Consequently, we propose that the formation of dimeric species occurs through the disproportionation of two hydroperoxo moieties in different $\left[\left(\mathrm{UO}_{2}\right)(\mathrm{OOH})\left(\mathrm{H}_{2} \mathrm{O}\right)\left(\mathrm{O}_{2}\right)_{2}\right]^{3-}$ species. Prior to the dimerization, we consider that a water ligand is expelled to form $\left[\left(\mathrm{UO}_{2}\right)(\mathrm{OOH})\left(\mathrm{O}_{2}\right)_{2}\right]^{3-}$ in order to keep the hexacoordination of both uranyl units in the dimer.

The dimerization involves the disproportionation of two $\mathrm{HOO}^{-}$to form $\mathrm{O}_{2}$ and two $\mathrm{OH}^{-}$groups. The $\mathrm{O}_{2}$ is released from aqueous solution as a gas and will promote the dimerization process (Le Châtelier principle). The later two hydroxo groups bridge between the two uranyl units. The dimerization of $\left[\left(\mathrm{UO}_{2}\right)(\mathrm{OOH})\left(\mathrm{O}_{2}\right)_{2}\right]^{3-}$ to form $\left[\left(\mathrm{UO}_{2}\right)(\mu-\mathrm{OH})_{2}\left(\mathrm{O}_{2}\right)_{4}\right]^{6-}$ is exergonic (Figure $4 \mathrm{a}$ ) due to the disproportionation of the hydroperoxo. The $(\mu-\mathrm{OH})_{2}$ dimer could evolve to $\left[\left(\mathrm{UO}_{2}\right)\left(\mu^{2}-\mathrm{O}_{2}\right)\left(\mathrm{O}_{2}\right)_{4}\right]^{6-}$ through a redox reaction with free hydroperoxo to form a bridging $\mu^{2}-\mathrm{O}_{2}$ between the uranyl moieties, water, and a free hydroxyl ion. The evolution of $\left[\left(\mathrm{UO}_{2}\right)(\mu-\mathrm{OH})_{2}\left(\mathrm{O}_{2}\right)_{4}\right]^{6-}$ to $\left[\left(\mathrm{UO}_{2}\right)\left(\mu^{2}-\mathrm{O}_{2}\right)\left(\mathrm{O}_{2}\right)_{4}\right]^{6-}$ is highly exergonic by ca. 36-38 $\mathrm{kcal} / \mathrm{mol}$ with respect to the $\left[\left(\mathrm{UO}_{2}\right)(\mathrm{OOH})\left(\mathrm{O}_{2}\right)_{2}\right]^{3-}$ monomers at both studied pHs. However, in the absence of alkali counterions, the evolution of $\left[\left(\mathrm{UO}_{2}\right)(\mu-\mathrm{OH})_{2}\left(\mathrm{O}_{2}\right)_{4}\right]^{6-}$ to two $\left[\left(\mathrm{UO}_{2}\right)(\mathrm{OH})\left(\mathrm{O}_{2}\right)_{2}\right]^{3-}$ monomers is slightly more favorable at the PBE/TZP level of theory. On the contrary, at the B3LYP/TZP level of theory, the dimerization to the peroxide dimer is always favored.

This mechanism is in agreement with the formation of $\mathrm{O}_{2}$ during the growth of uranyl-peroxide nanocapsules but also reveals the origin of the two main bridging ligands between the uranyl units (namely the $(\mu-\mathrm{OH})_{2}$ and $\left(\mu^{2}-\mathrm{O}_{2}\right)$ groups). The fundamental importance of the redox chemistry of peroxide in the dimerization process is also in agreement with the recent observations of Liao et al. ${ }^{39}$

Role of the alkali counterions. The influence of the alkali metal cations present in solution upon the final topology of uranylperoxide nanoclusters has been previously demonstrated both experimentally and computationally. ${ }^{29,34-36,59,60}$ One example is the $\left[\left(\mathrm{UO}_{2}\right)_{2}\left(\mathrm{O}_{2}\right)\left(\mathrm{C}_{2} \mathrm{O}_{4}\right)_{4}\right]^{6-}$ species, where X-ray crystallography indicates that the axes of the uranyl moieties are not parallel to one another, but instead tilted as a consequence of alkali metal cation-uranyl ion pairing (Figure 1a). Furthermore, there are no reports of uranyl-peroxide nanocapsules or their precursors synthetized in the absence of alkali metals or alkaline earth cations in solution. The required $\mathrm{pH}$ for the synthesis of such species is commonly achieved by using alkali hydroxides. From the computational viewpoint, several studies have shed some light on the importance of ion pairing for the structure, stability, and electronic structure of these species. ${ }^{29,35,36}$ However, the role of the counterions prior to the nanocapsule's formation (if any), e.g. in the growth of uranyl-peroxide nanocapsules, has remained unstudied.

Initially, we hypothesized that counterions play a catalytic role in the dimerization process and subsequent reactions towards the formation of nanocapsules. However, their incorporation into the products through strong ion pairs, and the absence of any additional experimental evidence in this respect, suggests that the alkali counterions are thermodynamically important because they stabilize the products through the formation of ion pairs. We have used the electrostatic potential (EP) to determine the position of the alkali counterions in the monomeric species prior to dimerization. For all of the studied species, the EP reveals that a large portion of the negative charge is concentrated on the yl-oxygen atoms and equatorial peroxide ligands, which will electrostatically attract the positively charged alkali counterions towards these positions. The contact ion-pairing energies of $\left[\left(\mathrm{UO}_{2}\right)(\mathrm{OOH})\left(\mathrm{O}_{2}\right)_{2}\right]^{3-}$ with $\mathrm{Li}^{+}$and $\mathrm{Na}^{+}$are exergonic by 3.0, and $2.7 \mathrm{kcal} / \mathrm{mol}$, respectively. These ion-pairing energies are significantly lower than the ones previously reported in the literature since we include the entropy loss due to the formation of the ion pair. If the contribution of entropy is neglected the calculated ion pairing enthalpies are similar to those previously reported and are exothermic by 11.1 and $10.4 \mathrm{kcal} / \mathrm{mol}$ for the $\mathrm{Li}^{+}$and $\mathrm{Na}^{+}$ion $\mathrm{pair}-$ ing with $\left[\left(\mathrm{UO}_{2}\right)(\mathrm{OOH})\left(\mathrm{O}_{2}\right)_{2}\right]^{3-}$.

We studied the dimerization of $\mathrm{X}\left[\left(\mathrm{UO}_{2}\right)(\mathrm{OOH})\left(\mathrm{O}_{2}\right)_{2}\right]^{2-}$ with $\mathrm{X}=$ alkali counterions, but only the sodium case is presented here (see supporting information for other ions). In both cases, the presence of the alkali counterions stabilized the $\mathrm{Na}_{2}\left[\left(\mathrm{UO}_{2}\right)(\mu-\mathrm{OH})_{2}\left(\mathrm{O}_{2}\right)_{4}\right]^{4-}$ and $\mathrm{Na}_{2}\left[\left(\mathrm{UO}_{2}\right)\left(\mu^{2}-\mathrm{O}_{2}\right)\left(\mathrm{O}_{2}\right)_{4}\right]^{4-}$ dimers by ca. $15 \mathrm{kcal} / \mathrm{mol}$ with respect to their alkali free counter- 
parts. Also, the formation of dimers is always favored with respect to the evolution to the $\mathrm{X}\left[\left(\mathrm{UO}_{2}\right)(\mathrm{OH})\left(\mathrm{O}_{2}\right)_{2}\right]^{2-} \mathrm{species}$. This demonstrates the fundamental role of the alkali counterions as a thermodynamic driving force in the formation of uranylperoxide dimers and in the formation of nanocapsules by stabilizing the products through ion-pairs.

Uranyl-peroxide building blocks and nanocapsules. The evolution of uranyl-peroxide dimers to larger aggregates may occur through a myriad of intermediates, the study of which is beyond the scope of the present work. However we studied the overall energetics for the formation of select species beyond dimers. First, we evaluated the energetics for the formation of the uranyl-peroxide tetramers and pentamers $\left(\left[\left(\mathrm{UO}_{2}\right)_{4}\left(\mu^{2}-\mathrm{O}_{2}\right)_{4}\left(\mathrm{O}_{2}\right)_{4}\right]^{8-}\right.$ and $\left.\left[\left(\mathrm{UO}_{2}\right)_{5}\left(\mu^{2}-\mathrm{O}_{2}\right)_{5}\left(\mathrm{O}_{2}\right)_{5}\right]^{10-}\right)$, proposed building blocks of larger nanocapsules. The formation of the pentamer is always favored over the tetramer, both enthalpically and in free energy (Table 1, Entries 1 and 2). The reaction enthalpies for the formation of these species starting from the $\left[\left(\mathrm{UO}_{2}\right)(\mathrm{OOH})\left(\mathrm{O}_{2}\right)_{2}\right]^{2-}$ monomer are -25.5 and $-38.5 \mathrm{kcal} / \mathrm{mol}$, respectively, whereas the Gibbs free energies of reaction are 45.4 and $-54.4 \mathrm{kcal} / \mathrm{mol}$, respectively. As was the case for the formation of the dimer, the release of $\mathrm{O}_{2}$ in these reactions contributes significantly to the favorable free energy observed.

Beyond the building blocks, we also studied the energetics for the formation of the two smallest reported uranylperoxide nanocapsules, $\left[\left(\mathrm{UO}_{2}\right)_{20}\left(\mu^{2}-\mathrm{O}_{2}\right)_{30}\right]^{20-}$ and $\left[\left(\mathrm{UO}_{2}\right)_{24}\left(\mu^{2}-\mathrm{O}_{2}\right)_{24}\left(\mu-\mathrm{O}_{2}\right)_{24}\right]^{24-}$, and we investigated the effect of the encapsulation of different species within their cavities. Due to the dynamic nature of the encapsulation and

a)

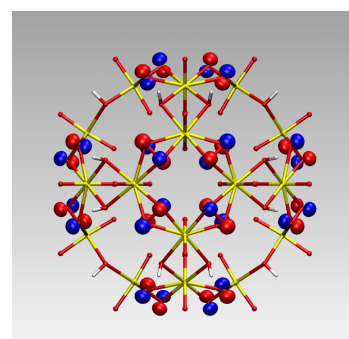

LUMO (5f Uranium)

b)

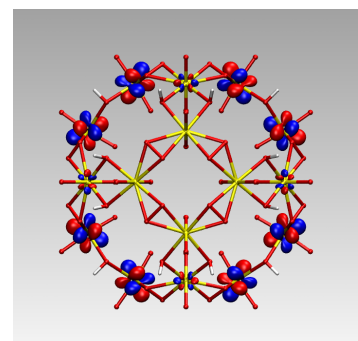

c)

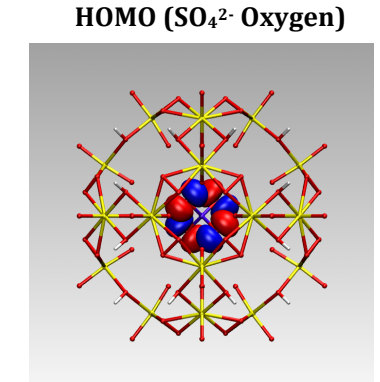

LUMO (5f Uranium)

d)

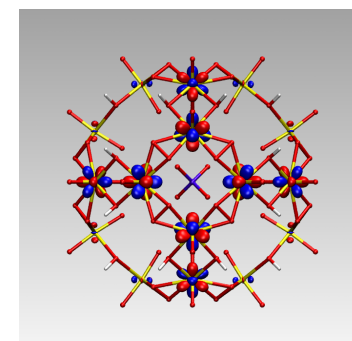

Figure 5. HOMO and LUMO of the $\mathrm{U}_{24}$ species $\left[\left(\mathrm{UO}_{2}\right)_{24}\left(\mu^{2}-\mathrm{O}_{2}\right)_{24}\left(\mu-\mathrm{O}_{2}\right)_{24}\right]^{24-}\left(\mathrm{a}\right.$ and b) and $\left(\mathrm{SO}_{4}\right) \mathrm{Li}_{6} \mathrm{~K}_{8} @\left[\left(\mathrm{UO}_{2}\right)_{24}\left(\mu^{2}-\mathrm{O}_{2}\right)_{24}(\mu-\right.$ $\left.\left.\mathrm{O}_{2}\right)_{24}\right]^{24-}(\mathrm{c}$ and d). Color code: Uranium in yellow, oxygen in red, and hydrogen in silver. Some orbitals have degeneracy $>1$ and only one orbital is presented, in consequence it might appear that the symmetry of the HOMO or LUMO is not the one of the species. Encapsulated alkali ions are not shown for clarity.

Table 1. Reaction enthalpies and free energies of $\left[\left(\mathrm{UO}_{2}\right)_{4}\left(\mu^{2}-\mathrm{O}_{2}\right)_{4}\left(\mathrm{O}_{2}\right)_{4}\right]^{8-},\left[\left(\mathrm{UO}_{2}\right)_{5}\left(\mu^{2}-\mathrm{O}_{2}\right)_{5}\left(\mathrm{O}_{2}\right)_{5}\right]^{10-},\left[\left(\mathrm{UO}_{2}\right)_{20}\left(\mu^{2}-\mathrm{O}_{2}\right)_{30}\right]^{20-}$ and $\left[\left(\mathrm{UO}_{2}\right)_{24}\left(\mu^{2}-\mathrm{O}_{2}\right)_{24}\left(\mu-\mathrm{O}_{2}\right)_{24}\right]^{24-}$ with and without alkali ions and small molecules. In parenthesis per number of uranyl units.

\begin{tabular}{|c|c|c|}
\hline Reactions & $\Delta \mathbf{H}^{\mathbf{o}}$ & $\Delta \mathbf{G}^{\mathbf{o}}$ \\
\hline $4\left[\left(\mathrm{UO}_{2}\right)(\mathrm{OOH})\left(\mathrm{O}_{2}\right)_{2}\right]^{3-} \rightarrow\left[\left(\mathrm{UO}_{2}\right)_{4}\left(\mu^{2}-\mathrm{O}_{2}\right)_{4}\left(\mathrm{O}_{2}\right)_{4}\right]^{8-}+2 \mathrm{O}_{2}+4 \mathrm{OH}^{-}$ & $-25.5(-6.4)$ & $-45.4(-11.3)$ \\
\hline $5\left[\left(\mathrm{UO}_{2}\right)(\mathrm{OOH})\left(\mathrm{O}_{2}\right)_{2}\right]^{3-} \rightarrow\left[\left(\mathrm{UO}_{2}\right)_{5}\left(\mu^{2}-\mathrm{O}_{2}\right)_{5}\left(\mathrm{O}_{2}\right)_{5}\right]^{10^{-}}+2.5 \mathrm{O}_{2}+5 \mathrm{OH}^{-}$ & $-38.5(-7.7)$ & $-54.4(-10.9)$ \\
\hline $12 \mathrm{Na}^{+}+20\left[\left(\mathrm{UO}_{2}\right)(\mathrm{OOH})\left(\mathrm{O}_{2}\right)_{2}\right]^{3-}+10 \mathrm{H}_{2} \mathrm{O} \rightarrow \mathrm{Na}_{12}\left[\left(\mathrm{UO}_{2}\right)_{20}\left(\mu^{2}-\mathrm{O}_{2}\right)_{30}\right]^{8-}+15 \mathrm{O}_{2}+40 \mathrm{OH}$ & $-63.2(-3.2)$ & $-102.5(-5.1)$ \\
\hline $24\left[\left(\mathrm{UO}_{2}\right)(\mathrm{OOH})\left(\mathrm{O}_{2}\right)_{2}\right]^{3-}+24 \mathrm{H}_{2} \mathrm{O} \rightarrow\left[\left(\mathrm{UO}_{2}\right)_{24}\left(\mu^{2-} \mathrm{O}_{2}\right)_{24}(\mu-\mathrm{OH})_{24}\right]^{24-}+24 \mathrm{O}_{2}+48 \mathrm{OH}^{-}$ & $-18.2(-0.8)$ & $-147.3(-6.1)$ \\
\hline $6 \mathrm{Na}^{+}+24\left[\left(\mathrm{UO}_{2}\right)(\mathrm{OOH})\left(\mathrm{O}_{2}\right)_{2}\right]^{3-}+48 \mathrm{H}_{2} \mathrm{O} \rightarrow \mathrm{Na}_{6} @\left[\left(\mathrm{UO}_{2}\right)_{24}\left(\mu^{2}-\mathrm{O}_{2}\right)_{24}(\mu-\mathrm{OH})_{24}\right]^{18-}+24 \mathrm{O}_{2}+24 \mathrm{OH}^{-}$ & $-184.8(-7.7)$ & $-263.7(-11.0)$ \\
\hline $8 \mathrm{Na}^{+}+6 \mathrm{Li}^{+}+24\left[\left(\mathrm{UO}_{2}\right)(\mathrm{OOH})\left(\mathrm{O}_{2}\right)_{2}\right]^{3-}+48 \mathrm{H}_{2} \mathrm{O} \rightarrow \mathrm{Li}_{6} \mathrm{Na}_{8} @\left[\left(\mathrm{UO}_{2}\right)_{24}\left(\mu^{2}-\mathrm{O}_{2}\right)_{24}(\mu-\mathrm{OH})_{24}\right]^{10-}+24 \mathrm{O}_{2}+24 \mathrm{OH}^{-}$ & $-404.1(-16.8)$ & $-414.9(-17.3)$ \\
\hline $8 \mathrm{~K}^{+}+6 \mathrm{Li}^{+}+24\left[\left(\mathrm{UO}_{2}\right)(\mathrm{OOH})\left(\mathrm{O}_{2}\right)_{2}\right]^{3-}+48 \mathrm{H}_{2} \mathrm{O} \rightarrow \mathrm{Li}_{6} \mathrm{~K}_{8} @\left[\left(\mathrm{UO}_{2}\right)_{24}\left(\mu^{2}-\mathrm{O}_{2}\right)_{24}(\mu-\mathrm{OH})_{24}\right]^{10-}+24 \mathrm{O}_{2}+24 \mathrm{OH}^{-}$ & $-459.5(-19.1)$ & $-463.5(-19.3)$ \\
\hline $\mathrm{SO}_{4} 4^{2-}+8 \mathrm{~K}^{+}+6 \mathrm{Li}^{+}+24\left[\left(\mathrm{UO}_{2}\right)(\mathrm{OOH})\left(\mathrm{O}_{2}\right)_{2}\right]^{3-}+48 \mathrm{H}_{2} \mathrm{O} \rightarrow\left(\mathrm{SO}_{4}\right) \mathrm{Li}_{6} \mathrm{~K}_{8} @\left[\left(\mathrm{UO}_{2}\right)_{24}\left(\mu^{2}-\mathrm{O}_{2}\right)_{24}(\mu-\mathrm{OH})_{24}\right]^{12-}+24 \mathrm{O}_{2}+24 \mathrm{OH}^{-}$ & $-448.9(-18.7)$ & $-435.0(-18.1)$ \\
\hline
\end{tabular}

the lack of highly ordered structures inside the nanocapsules' cavities in aqueous solution, we compare our results with experimental crystal structures instead of aqueous species; however, we have recently developed a uranyl-peroxide force field towards exploring the dynamics within these cavities in aqueous solution. ${ }^{37}$ The reaction enthalpies and free energies for the formation of $\left[\left(\mathrm{UO}_{2}\right)_{20}\left(\mu^{2}-\mathrm{O}_{2}\right)_{30}\right]^{20-}$ and $\left[\left(\mathrm{UO}_{2}\right)_{24}\left(\mu^{2}-\mathrm{O}_{2}\right)_{24}(\mu-\mathrm{OH})_{24}\right]^{24-}$ species with different encapsulated counterions are presented in entries 4-10 of Table 1.

The experimental X-ray structure of $\left[\left(\mathrm{UO}_{2}\right)_{20}\left(\mu^{2}-\mathrm{O}_{2}\right)_{30}\right]^{20-}$ contains 12 edge sharing pentagons (dodecahedron), with a sodium alkali cation under each one. ${ }^{19}$ The positions of the remaining counterions outside the nanocapsule are unknown due to disorder within the crystal structure. On one hand, the formation of this nanocapsule from $\left[\left(\mathrm{UO}_{2}\right)(\mathrm{OOH})\left(\mathrm{O}_{2}\right)_{2}\right]^{3-}$ is not favorable enthalpically (endothermic) in the absence of counterions $(+144.0 \mathrm{kcal} / \mathrm{mol}$ ); however, the presence of one sodium under each pentagonal face makes the formation of this nanocapsule favorable $(-63.2 \mathrm{kcal} / \mathrm{mol})$. Note that the Gibbs free energies of reaction are favorable in all of the cases studied herein due to the increase of entropy induced by release of molecular oxygen and hydroxo species during the reaction. 
On the other hand, $\left[\left(\mathrm{UO}_{2}\right)_{24}\left(\mu^{2}-\mathrm{O}_{2}\right)_{24}(\mu-\mathrm{OH})_{24}\right]^{24-}$ has six topological squares and eight topological hexagons; the latter contains both peroxo and hydroxo bridges between the uranyl units. ${ }^{3}$ This nanocapsule has a larger cavity and experimentally has small ions like $\mathrm{Li}^{+}$and $\mathrm{Na}^{+}$under the square faces and larger ions under the hexagonal faces like $\mathrm{K}^{+}$or $\mathrm{Cs}^{+}$. The formation of this nanocapsule with either Li or Na under the square faces (and no ion under the hexagonal faces) is almost isoenergetic (differing by only a few $\mathrm{kcal} / \mathrm{mol}$ in both $\Delta \mathrm{H}^{\circ}$ and $\Delta \mathrm{G}^{\circ}$ ). However, if in addition to the counterions under the topological squares, we also consider cations under the topological hexagons, we find that the formation of Li6 $\mathrm{K}_{8} @$ $\left[\left(\mathrm{UO}_{2}\right)_{24}\left(\mu^{2}-\mathrm{O}_{2}\right)_{24}(\mu-\mathrm{OH})_{24}\right]^{10-}$ is more favorable than its analogous $\mathrm{Li}_{6} \mathrm{Na}_{8} @\left[\left(\mathrm{UO}_{2}\right)_{24}\left(\mu^{2}-\mathrm{O}_{2}\right)_{24}(\mu-\mathrm{OH})_{24}\right]^{10-}(-459.5 \mathrm{vs} .-404.1$ $\mathrm{kcal} / \mathrm{mol}$ in $\left.\Delta \mathrm{H}^{\circ}\right)$. Finally, we considered the co-encapsulation of a sulfate ion $\left(\mathrm{SO}_{4}\right) \mathrm{Li}_{6} \mathrm{~K}_{8} @\left[\left(\mathrm{UO}_{2}\right)_{24}\left(\mu^{2}-\mathrm{O}_{2}\right)_{24}(\mu-\mathrm{OH})_{24}\right]^{12-}, \mathrm{but}$ its formation is less favorable than the structure without sulfate $\left(-448.9 \mathrm{vs} .-459.5 \mathrm{kcal} / \mathrm{mol}\right.$ in $\left.\Delta \mathrm{H}^{\circ}\right)$. We hypothesize that this is a consequence of the mismatch between the tetrahedral symmetry of the sulfate ion and the $U_{24}$ nanocapsule's symmetry (octahedral). This symmetry mismatch does not allow for a perfect and directional interaction between the sulfate and the capsule/encapsulated ions as seen in other nanocapsules such as $\left[\left(\mathrm{UO}_{2}\right)_{28}\left(\mu^{2}-\mathrm{O}_{2}\right)_{42}\right]^{28-}$ with tetrahedral ions. ${ }^{38} \mathrm{Fur}-$ thermore, encapsulation of sulfate led to a change in the electronic structure of the capsule (see Figure 5). In uranylperoxide nanocapsules, the HOMOs are predominantly composed of peroxide oxygen contributions (p orbitals) while the LUMOs are a combination of primarily empty f orbitals. ${ }^{29,35,36,38}$ In the case with sulfate, the sulfate orbitals sit in the HOMOLUMO gap of the nanocapsule.

\section{Conclusions}

In conclusion, we have studied the speciation of the uranyl ion under two different experimental conditions and explored the formation of uranyl-peroxide dimers via a ligand exchange mechanism. The dominant monomeric species under basic peroxidic conditions are $\left[\left(\mathrm{UO}_{2}\right)\left(\mathrm{H}_{2} \mathrm{O}\right)_{2}\left(\mathrm{O}_{2}\right)_{2}\right]^{2-}$, $\left[\left(\mathrm{UO}_{2}\right)\left(\mathrm{H}_{2} \mathrm{O}\right)(\mathrm{OOH})\left(\mathrm{O}_{2}\right)_{2}\right]^{3-}$, and $\left[\left(\mathrm{UO}_{2}\right)(\mathrm{OOH})\left(\mathrm{O}_{2}\right)_{2}\right]^{3-}$. The dimerization process occurs through the disproportionation of peroxide to form two bridging hydroxide ligands and free molecular oxygen. The formation of the $(\mu-\mathrm{OH})_{2}$ dimer is followed by a redox reaction with free hydroxide to form $\left[\left(\mathrm{UO}_{2}\right)\left(\mu^{2}-\mathrm{O}_{2}\right)\left(\mathrm{O}_{2}\right)_{4}\right]^{6-}$. This confirms the essential role of the redox chemistry of peroxide in the dimerization process. The alkali counterions stabilize the dimers by acting as a thermodynamic driving force in the formation of uranyl-peroxide nanocapsules (ion pairing), together with the disproportionation of peroxide.

The proposed mechanism is in agreement with the observed formation of molecular oxygen during the growth of uranyl-peroxide nanocapsules and explains the origin of the two main bridging ligands between the uranyl units in the capsules, $(\mu-\mathrm{OH})_{2}$ and $\left(\mu^{2}-\mathrm{O}_{2}\right)$. However, we emphasize that the formation of the nanocapsules is a self-assembly process in which the formation of uranyl peroxide units is reversible (unlike polymers where once a $\mathrm{C}$ - $\mathrm{C}$ bond is formed, it is irreversible), and the stability of different species or nanocapsules is influenced by the $\mathrm{pH}$, the nature of the counterions, solubility, and temperature.

We studied the overall energetics for the formation of the square and pentagonal building blocks as well as two nanocapsules containing 20 or 24 uranium centers. We demonstrate that the formation of the square building block is less favorable than the pentagonal one. Likewise, the formation of $U_{20}$ is less favorable than $U_{24}$. Moreover these species are all accessible if the experimental conditions are chosen appropriately. Finally, we explored the role of counterions in the nanocapsules, and found for the dimer, they play an important role in the stabilization of such species through ion pairs.

\section{ASSOCIATED CONTENT}

Supporting Information Available: Additional computational details and a cif file with all of the coordinates of the studied species. This material is available free of charge via the Internet at http://pubs.acs.org.

\section{AUTHOR INFORMATION}

\section{Corresponding Author}

* Pere Miró (pere.ramirez@northwestern.edu)

\section{Author Contributions}

The manuscript was written through contributions of all authors. All authors have given approval to the final version of the manuscript.

\section{ACKNOWLEDGMENT}

P.M. acknowledge the funding of U.S. National Science Foundation (CHE09-52054). PCB, MN and BV were supported by the Materials Science of Actinides Center, an Energy Frontier Research Center funded by the U.S. Department of Energy, Office of Science, and Office of Basic Energy Sciences under Award Number DE-SC0001089. PM and BV thank Profs. Christopher J. Cramer and Laura Gagliardi.

\section{REFERENCES}

(1) United States Nuclear Regulatory Commission (U.S.NRC) www.nrc.gov.

(2) Nyman, M.; Burns, P. C. Chem. Soc. Rev. 2012, 41, 7354.

(3) Burns, P. C.; Kubatko, K. A.; Sigmon, G.; Fryer, B. J.; Gagnon, J. E.; Antonio, M. R.; Soderholm, L. Angew. Chem. Int. Ed. 2005, 44, 2135. 
Tiferet, E.; Gil, A.; Bo, C.; Shvareva, T. Y.; Nyman, M.; Navrotsky, A. Chem. Eur. J. 2014, 20, 3646. Qiu, J.; Burns, P. C. Chem. Rev. 2013, 113, 1097.

. Wallace, C. M.; Qiu, J.; Szymanowski, J. E.; Sigmon, G. E.; Burns, P. C. Inorg. Chem. 2013, 52, 7673.

Adelani, P. O.; Sigmon, G. E.; Burns, P. C. Inorg. Chem. 2013, 52, 6245.

.

Miro, P.; Ling, J.; Qiu, J.; Burns, P. C.; Gagliardi, L.; Cramer, C. J. Inorg. Chem. 2012, 51, 8784.

.

Qiu, J.; Ling, J.; Jouffret, L.; Thomas, R.; Szymanowski, J. E. S.; Burns, P. C. Chem. Sci. 2014, 5, 303.

Qiu, J.; Ling, J.; Sieradzki, C.; Nguyen, K.; Wylie, E. M.; Szymanowski, J. E.; Burns, P. C. Inorg. Chem. 2014, 53, 12084.

Ling, J.; Qiu, J.; Burns, P. C. Inorg. Chem. 2012, 51, 2403.

(14) Ling, J.; Qiu, J.; Sigmon, G. E.; Ward, M.; Szymanowski, J. E.; Burns, P. C. J. Am. Chem. Soc. 2010, 132, 13395.

(15) Ling, J.; Qiu, J.; Szymanowski, J. E.; Burns, P. C. Chem. Eur. J. 2011, 17, 2571.

(16) Liao, Z.; Ling, J.; Reinke, L. R.; Szymanowski, J. E.; Sigmon, G. E.; Burns, P. C. Dalton Trans. 2013, 42, 6793.

(17) Unruh, D. K.; Ling, J.; Qiu, J.; Pressprich, L.; Baranay, M.; Ward, M.; Burns, P. C. Inorg. Chem. 2011, 50, 5509.

(18) Sigmon, G. E.; Burns, P. C. J. Am. Chem. Soc. 2011, 133, 9137.

(19) Sigmon, G. E.; Ling, J.; Unruh, D. K.; Moore-Shay, L.; Ward, M.; Weaver, B.; Burns, P. C. J. Am. Chem. Soc. $2009,131,16648$.

(20) Sigmon, G. E.; Unruh, D. K.; Ling, J.; Weaver, B.; Ward, M.; Pressprich, L.; Simonetti, A.; Burns, P. C. Angew. Chem. Int. Ed. $2009,48,2737$.

(21) Sigmon, G. E.; Weaver, B.; Kubatko, K. A.; Burns, P. C. Inorg. Chem. 2009, 48, 10907.

(22) Burns, P. C.; Hughes, K. A. Am. Mineral. 2003, 88, 1165.

(23) Kubatko, K. A.; Burns, P. C. Inorg. Chem. 2006, 45, 6096.

(24) Kubatko, K. A.; Forbes, T. Z.; Klingensmith, A. L.; Burns, P. C. Inorg. Chem. 2007, 46, 3657.

(25) Wylie, E. M.; Peruski, K. M.; Weidman, J. L.; Phillip, W. A.; Burns, P. C. ACS Appl. Mater. Inter. 2014, 6, 473.

(26) Liu, Y.; Czarnecki, A.; Szymanowski, J. E. S.; Sigmon, G. E.; Burns, P. C. J. Radioanal. Nucl. Ch. 2015, $303,2257$.

Armstrong, C. R.; Nyman, M.; Shvareva, T.; Sigmon, G. E.; Burns, P. C.; Navrotsky, A. Proc. Natl. Acad. Sci. USA 2012, $109,1874$.

For clarity we will omit the peroxide coordination patern ( $\eta$ and $\mu$ ).

(29) Miro, P.; Pierrefixe, S.; Gicquel, M.; Gil, A.; Bo, C. J. Am. Chem. Soc. 2010, 132, 17787.

(30) Zanonato, P. L.; Di Bernardo, P.; Grenthe, I. Dalton Trans. 2012, 41, 3380.

(31) Zanonato, P. L.; Di Bernardo, P.; Grenthe, I. Dalton Trans. 2014, 43, 2378.

(32) Zanonato, P. L.; Di Bernardo, P.; Szabo, Z.; Grenthe, I. Dalton Trans. 2012, 41, 11635.

(33) Zanonato, P. L.; Di Bernardo, P.; Vallet, V.; Szabo, Z.; Grenthe, I. Dalton Trans. 2015, 44, 1549.

(34) Qiu, J.; Vlaisavljevich, B.; Jouffret, L.; Nguyen, K.; Szymanowski, J. E.; Gagliardi, L.; Burns, P. C. Inorg. Chem. $2015,54,4445$.

(35) Vlaisavljevich, B.; Gagliardi, L.; Burns, P. C. J. Am. Chem. Soc. 2010, 132, 14503.

(36) Miro, P.; Bo, C. Inorg. Chem. 2012, 51, 3840.

(37) Miro, P.; Vlaisavljevich, B.; Dzubak, A. L.; Hu, S. X.; Burns, P. C.; Cramer, C. J.; Spezia, R.; Gagliardi, L. J. Phys. Chem. C 2014, 118 , 24730.

(38) Gil, A.; Karhanek, D.; Miro, P.; Antonio, M. R.; Nyman, M.; Bo, C. Chem. Eur. J. 2012, 18, 8340.

(39) Liao, Z.; Deb, T.; Nyman, M. Inorg. Chem. 2014, 53, 10506.

(40) Nyman, M.; Rodriguez, M. A.; Campana, C. F. Inorg. Chem. 2010, 49, 7748.

(41) Vila-Nadal, L.; Rodriguez-Fortea, A.; Yan, L. K.; Wilson, E. F.; Cronin, L.; Poblet, J. M. Angew. Chem. Int. Ed. 2009, $48,5452$.

(42) Vila-Nadal, L.; Wilson, E. F.; Miras, H. N.; Rodriguez-Fortea, A.; Cronin, L.; Poblet, J. M. Inorg. Chem. 2011, 50, 7811.

(43) ADF2013, SCM, Theoretical Chemistry, Vrije Universiteit, Amsterdam, The Netherlands.

(44) Guerra, C. F.; Snijders, J. G.; te Velde, G.; Baerends, E. J. Theor. Chem. Acc. 1998, 99, 391.

(45) te Velde, G.; Bickelhaupt, F. M.; Baerends, E. J.; Fonseca Guerra, C.; van Gisbergen, S. J. A.; Snijders, J. G.; Ziegler, T. J. Comp. Chem. 2001,

(46) Vosko, S. H.; Wilk, L.; Nusair, M. Can. J. Phys. 1980, 58, 1200.

(47) Perdew, J. P.; Burke, K.; Ernzerhof, M. Phys. Rev. Lett. 1996, 77, 3865.

(48) van Lenthe, E.; Baerends, E. J.; Snijders, J. G. J. Chem. Phys. 1993, 99, 4597.

(49) van Lenthe, E.; Baerends, E. J.; Snijders, J. G. J. Chem. Phys. 1994, 101, 9783.

(50) Cramer, C. J. Essentials of Computational Chemistry: Theories and Models; 2nd ed.; Wiley, 2004.

(51) Klamt, A. J. Phys. Chem. 1995, 99, 2224.

(52) Klamt, A.; Schuurmann, G. Perkin Trans. 2 1993, 799.

(53) Allinger, N. L.; Zhou, X. F.; Bergsma, J. Comp. Theor. Chem. 1994, 118, 69.

(54) Kelly, C. P.; Cramer, C. J.; Truhlar, D. G. J. Phys. Chem. B 2006, 110, 16066

(55) CRC Handbook of Chemistry and Physics 95th Edition (2014).

(56) Hagberg, D.; Karlstrom, G.; Roos, B. O.; Gagliardi, L. J. Am. Chem. Soc. 2005, 127, 14250.

(57) Hay, P. J.; Martin, R. L.; Schreckenbach, G. J. Phys. Chem. A 2000, 104, 6259.

(58) Wahlgren, U.; Moll, H.; Grenthe, I.; Schimmelpfennig, B.; Maron, L.; Vallet, V.; Gropen, O. J. Phys. Chem. A 1999, $103,8257$.

(59) Alam, T. M.; Liao, Z.; Zakharov, L. N.; Nyman, M. Chem. Eur. J. 2014, $20,8302$.

(60) Nyman, M.; Alam, T. M. J. Am. Chem. Soc. 2012, 134, 20131. 